\title{
Prevalence and predictors of emotional and behavioral problems among rural school Egyptian adolescents
}

\author{
Maha Mowafy, MD *, Dalia Ahmed, MD **, Eman F Halawa, MD***, Maha Emad El Din, MD ${ }^{* * * *}$ \\ * Community Medicine Department, Cairo University \\ **** Pediatrics Department, Cairo University \\ ${ }^{* * * * *}$ Psychiatric Department, Beni Sueif University
}

\begin{abstract}
BACKGROUND: Emotional and behavioral problems among adolescents are common problems in developing and developed countries with a great impact on their health and wellbeing. The OBJECTIVE is to determine prevalence, predictors and impact of emotional and behavioral problems among rural adolescents' school children.

METHODS: A cross sectional study with multistage random sample was taken from Giza governorate rural school students aged 13 to 17 years during the academic year 2012-2013. A sample of 476 students was selected. Psychological assessment was conducted using selfreported strengths and difficulties questionnaire (SDQ).
\end{abstract}

RESULTS: The study showed that $18.5 \%$ of students had behavioral problems with the highest proportion in emotional problems followed by conduct problems, hyperactive problems and lastly peer relations. Abnormal impact score was found in $13.7 \%$ of studied students. Students from private school, at secondary educational grade, with separated or dead parent and frequently punished at school were significant predictors of behavioral problems.

CONCLUSIONS: Students from private schools, secondary education, with separated or dead parent, and frequently punished were at higher risk to have behavioral abnormalities than others. School teachers need proper training on how to communicate properly with their adolescent students aiming to avoid frequent punishments.

Key words: Adolescents, emotional and behavioral problems, rural, Egypt.

\section{Introduction}

Emotional and behavioral problems among adolescents represents a considerable public health problem in developing countries; despite being less widely studied than causes of physical mortality and morbidity. ${ }^{1-3}$ In developed countries emotional and behavioral disorders represents around $12 \%$ of the overall load of morbidity. Evolving researches from developing countries suggests similar levels of morbidity although strong epidemiological evidence is poor. ${ }^{4}$ It is essential to have true and up-to-date information about the prevalence of these problems to be able to guide the health policies in these countries. ${ }^{5}$

Adolescents have to experience sudden changes in their environment, since they begin to take on different social roles. The speedy social change and development are associated with greater emotional and behavioral health risks. Their physical body exceeds their emotional maturity, and their peer pressure usually override their common sense. $^{6}$

Emotional and behavioral problems have serious negative consequences for adolescents' academic achievement and social development. ${ }^{7}$ These problems could 
be accompanied with chronic health problems or intensifying the present medical problems, like substance abuse and suicidal behaviors. ${ }^{(8,9)}$

Many sociodemographic factors as socioeconomic status, interpersonal factors and family pressures are known to increase the risk of emotional and behavioral problems in adolescents. ${ }^{10}$ Special concerns should be given to those students aiming to control these problems.

The objectives of the study are to measure the prevalence and the predicting risk factors of behavioral problems among adolescents in preparatory and secondary school among the studied group. Also we aimed to study the impact of behavioral problems on students and people around them and to its predicting risk factors

\section{Methods}

\section{Participants}

In this cross sectional study a multistage random sample was collected from the target population including preparatory and secondary school students from 13 to 17 years old in Nikla rural village in Giza governorate. Students known to have neuropsychiatric disorders or severe chronic diseases or not within this age group were excluded from the study.

West Menshaat el Khanater was randomly selected out of the 22 directorates in Giza governorate. The selected directorate had 11 villages from which Nikla village was randomly selected to be the site of the study; it has a population census of 25717 people for the year 2012. Data were collected in the academic year 2012 - 2013 from the four schools in Nikla village; after taking the permission from the Ministry of Education. The four schools include three public schools (two preparatory and one secondary) in addition to a private secondary one; all of which were addressed in the study. A systematic randsample of 500 students was systematic randomly selected from all schools (every $5^{\text {th }}$ student was taken). Out of 500 students 476 participated in the study after the approval of their caregiver and their agreement to participate

Sample size calculation was done using Epi Info program version 3.5.3. At $95 \%$ confidence interval, population size (number of students registered in the selected village schools in the academic year 2012-2013 in preparatory and secondary educational grade) was 2172 students, problem frequency is $24.45 \%{ }^{(11)}$ and $5 \%$ margin of error, the calculated sample size was 251 participants. Using design effect $=1.8^{(12)}$ and nonresponsive rate $10 \%$ yield a sample size of 497 students. A sample of 500 students was selected with 476 responded and participated (response rate 93.4\%).

\section{Instrumentation}

Data collection was done using a pre-tested, self-administrated questionnaire guided by researcher's instructions. The questionnaire probed the following variables:

First: Socio-demographic variables: including age, sex, parents' education and occupation, marital status, number of children in the family, child order and exposure to domestic physical violence. Socioeconomic status was classified into low, middle and high classes according to: Parental highest level of education and work and crowding index. Scoring from 19-25 is high social class, 12-18 middle social class, while less than 12 is low social class. ${ }^{(13)}$ Second: school variables including school type (public or private), school grade (preparatory or secondary), frequent absence from school, frequency of punishment and scholastic achievements. Also students were asked about smoking and substance abuse. Third: The self-reported version of Strengths and Difficulties Questionnaire (SDQ) which is a brief behavioral screening questionnaire 
that includes 25 questions and 5 scales. Each of the 5 scales includes 5 questions and a scale ranging from 0 to 10 . The 5 scales are: emotional symptoms, conduct problems, (hyperactivity/inattention) peer relationship problems and prosocial behavior. The total difficulties score is generated by summing the scores from all the scales except the prosocial scale. The resultant score can range from 0 to 40 . The cut point of SDQ was regarded 10 for adolescents. ${ }^{14}$ The impact supplement enquires about chronicity, distress, social impairment, and burden for others. It includes 5 questions and a scale ranged from 0 to 10 . Subtotal, total and impact scores are classified as normal, borderline and abnormal. The cut off point for abnormal total impact scores is 2 or more is abnormal. The psychometric properties of the Arabic version of the SDQ have been validated in 2 former Arabic samples. ${ }^{15,16}$

\section{Data analysis}

The data was coded and entered using the statistical package SPSS version 15 . The data was summarized using descriptive statistics: mean standard deviation and range for quantitative variables and number and percentage for qualitative values. Statistical differences between groups were tested using Chi Square test (or Fisher's Exact test when expected cell count is $<5$ ) for qualitative variables. Correlations were done to test for linear relations between variables. Logistic regression analysis was done to test for significant predictors of behavioral problem or impact score. P- value less than or equal to 0.05 was considered statistically significant.

\section{Results}

A total of 476 children, aged 13-17 years, were enrolled in the study. Table $1 \mathrm{a} \& 1 \mathrm{~b}$ presents characteristics of the studied group with $89.5 \%$ from public schools and $54.6 \%$ in the preparatory educational grade. About half $(54.6 \%)$ of the students were males with mean age $15.2 \pm 1.5$ years. $10.7 \%$ of students have separated or one dead parent. $65.9 \%$ of students fathers were secondary or highly educated and $62.5 \%$ had semiprofessional or professional jobs. Regarding the maternal education, only $31.9 \%$ were secondary or highly educated and the majority $(90.5 \%)$ were not working. $65.5 \%$ of students' were from middle social level families. $2.3 \%$ of students were smoker and $5.7 \%$ ever tried drugs. $29 \%$ of students reported frequent absence from schools, $10.3 \%$ had poor scholastic achievements and 5\% were frequently punished at school (physical and/or verbal).

Table $2 \mathrm{a} \& 2 \mathrm{~b}$ summarizes the results from the self-reported completed SDQs, describing the prevalence of abnormal symptom and impact scores. $18.5 \%$ of students had abnormal behavior. The highest proportion of abnormal behavior was for emotional problems followed by conduct problems, hyperactive problems and lastly peer relations. $15.7 \%$ of students perceived themselves as having emotional or behavioral difficulties and $13.7 \%$ of them had impact scores in the abnormal band. Tables 3 and 4 show the association between abnormal behavior and impact scores with different variables of the studied group. A significantly higher proportion of abnormal behavior was found among students who were from private school, had separated or dead parent, exposed to domestic physical violence, were frequently absent from school without obvious reasons or were frequently punished at school. Regarding abnormal impact score: it was significantly higher among students who were at secondary educational grade, had a working mother, were smokers, exposed to domestic physical violence, frequently punished at 
school or were frequently absent from school without obvious reasons.

Correlations done between SDQ scores and different studied variables found that students age was positively correlated with emotional symptoms scale ( $\mathrm{p}$ value $=.001$ and $\mathrm{r}=.152$ ), hyperactive scale ( $\mathrm{p}$ value $<.001$ and $\mathrm{r}=.202)$, total difficulties score $(\mathrm{p}$ value $=.006$ and $r=.126)$ and impact score $(\mathrm{p}$ value $<.001$ and $r=.171)$. Family size was negatively correlated with prosocial scale $(\mathrm{p}$ value $=.022$ and $r=-.105)$. Social score was negatively correlated with peer problem scale ( $\mathrm{p}$ value $=.03$ and $\mathrm{r}=-.100$ ). While no correlation was found with sibling number, child order or crowding index. Impact score was positively correlated with emotional symptoms scale ( $\mathrm{p}$ value <.001 and $\mathrm{r}=.249$ ), conduct problem scale ( $\mathrm{p}$ value $<.001$ and $\mathrm{r}=.203$ ), hyperactive scale ( $\mathrm{p}$ value $<.001$ and $\mathrm{r}=.228$ ) and total difficulties score ( $\mathrm{p}$ value $<.001$ and $\mathrm{r}=.278$ ).

In table 5 logistic regression analyses was done to test for significant predictors for total difficulties score and impact score abnormalities. For total behavior abnormalities: school type, educational grade, marital status, domestic violence exposure, frequent absence from school and punishment at school were entered in the regression model but only students who were from private school, at secondary educational grade, had separated or dead parent, and were frequently punished at school were at higher risk to have behavioral abnormalities than other students.

Regarding abnormal impact score: student age, educational grade, maternal work, smoking, domestic violence exposure, frequent absence from school, punishment at school and behavioral problem were entered in the regression model but only students who were at secondary educational grade, had working mother, were smokers, were frequently punished at school and had behavioral problems were at higher risk to have abnormal impact score than other students.

\section{Discussion}

The main objective of this cross-sectional study was to find out the prevalence of behavioral problems in a sample of rural adolescent students in Giza Governorate, Egypt and its association with different sociodemographic variables using the SDQ. The reliability and validity of the SDQ made it a useful brief measure of the psychopathology of children and adolescents. ${ }^{(14)}$ Being used worldwide allows comparisons with results from other countries and cultures. It was found that $18.5 \%$ of the adolescent students in the present study had an abnormal total behavioral score. This is very close to a similar study in Brazil $(18.7 \%)^{(17)}$, but higher than that reported in India $(10.4 \%)^{(18)}$, Gaza strip $(14.2 \%)^{(19)}$ and $9.5 \%$ in Britain. ${ }^{(20)}$ This was lower than that from Egypt $(20.6 \%)^{(11)}$, Iran $(24.4 \%)^{(21)}$ and Bangladesh $(22 \%)^{6}$ and Pakistan $(35 \%){ }^{22}$ These differences may be due to different sociodemographic, cultural factors, and sources of information.

In the present study, emotional problems were the most prevalent problems (19\%) which is consistent with similar studies from Brazil (17), Gaza ${ }^{(19)}$ and Siberia. ${ }^{(23)}$ However, this was different from similar studies from Egypt, India and Iran which found that conduct problems were the most common. $(11,18,24,25)$ Another Chinese study found out that peer problems were the most common problems. ${ }^{(26)}$ The higher prevalence of emotional problems in this study compared to higher prevalence of behavioral problems (hyperactivity and conduct scale) in other studies used teacher and parent forms may be due the fact that parents are more likely not aware of a adolescent's emotional condition and students may be unconcerned 
of the consequences of their behavioral problems or may hide a problem. ${ }^{(27)}$ Also the age of our subjects from 13-17 years may raise the prevalence of emotional disorder, as prevalence of emotional disorder increase with age.

Students from secondary schools were at significant higher risk of total difficulty score and difficulty impact score. This agrees with similar studies from Bangladesh, Iran and Greece. ${ }^{(6,28,29)}$ This might be explained by increasing academic pressure, difficulties in adjustment with their families, peers and teachers or difficulties in adjustment with rapid transition of their lives.

The total difficulty score was significantly higher among students with separated parents or dead parent compared to students with two-parent families. This was consistent with a similar survey by Pastor et al and Pathak et al who found out that the prevalence of behavioral problems was twice in mother-only families than in biological nuclear families. ${ }^{30,31}$ This might be explained by positive relation between the proper adolescent adjustment and the family structure.

In the present study, it was found that exposure to frequent punishment was a significant predictor of total difficulty score and difficulty impact score. This was consistent with previous literature that found out significantly higher association between physical violence and frequent corporeal punishment with behavioral problems and hence abnormally impact score. ${ }^{(32-34)}$ This is against the United Nations' Committee on the Rights of the Child General Comment No. 8 and so the policy makers should take all appropriate legislative, administrative, social and educational measures to eliminate this abuse of punishment. (35)

The presence of working mother was significantly associated with difficulty impact score in the present work. This agrees with $\underline{\text { Strazdins }}$ et al who found out similar results. ${ }^{(36)}$ This could be because maternal employment could hamper mothers' capacity to care. By contrast, theories of child mental health often view fathers' employment as necessary and beneficial for children's and adolescents' wellbeing. Further studies should consider whether mothers' and fathers' rewards from combining employment with childcare may be protective for children's mental health, and whether their conflicts and dilemmas generate risks.

The use of the SDQ to measure emotional and behavioral problems in adolescents is a strength of the present study. Research by Kessler and colleagues has shown that the brief version of the SDQ is a reliable and valid instrument for screening psychiatric disorders in adolescents. ${ }^{37}$

\section{Limitations}

1-The sampling unit for the present study was schools, which was most feasible method of recruiting and assessing children in Pakistan therefore the generalizability of findings of this study is limited only to school attending children.

2- This was a single informant assessment of the behavioral problems and not from the teachers nor the parents. In future research, the authors recommend to analyze multi informants and explore potential differences between every two different informants which would provide surplus value of consulting multiple informants in screening behavioral problems to get a complete picture

\section{Conclusion}

Emotional and behavioral problems are common among Egyptian adolescents. Students from private schools, secondary education, with separated or dead parent and frequently punished were at higher risk to have behavioral abnormalities than others. 


\section{Implications For School Health} Specific screening programs to train, sensitize and mobilize teachers and parents regarding adolescents' emotional and behavioral problems are urgently needed in Egypt especially among high risk adolescents. School teachers need proper training of how to communicate properly with their adolescent students aiming to avoid frequent punishments.

\section{Human Subjects Approval Statement} The study was approved by the Central Agency for Public Mobilization and Statistics and the Ministry of Education, Egypt. Also, the approval of institutional review board of the family medicine department at Cairo University was obtained for both scientific and ethical considerations of the study. A written informed consent was obtained from the parents before enrollment of the students in the study. Student participation was voluntary after parent's agreement.

\section{References}

1) Fayyad J, Jahshan C, Karam E. Systems development of child mental health services in developing countries. Child Adolesc Psychiatr Clin N Am. 2001;10(4):745-62.

2) Patel V, Flisher AJ, Hetrick $S$, McGorry $\mathbf{P}$. Mental health of young people: a global public-health challenge. Lancet. 2007;369(9569):1302-13.

3) Rahman A, Mubbashar M, Harrington R, Gater R. Annotation: Developing child mental health services in developing countries. J Child Psychol Psychiatry. 2000;41(05):539-46.

4) Mullick MSI, Goodman R. The prevalence of psychiatric disorders among 5-10 year olds in rural, urban and slum areas in Bangladesh. Soc Psychiatry Psychiatr Epidemiol. 2005;40(8):663-71.

5) Afifi M. Mental health publications from the Arab world cited in PubMed, 19872002. East Mediterr Health J. 2005;11(3):319.

6) Hossain S. A Study of Determining the Relationship between Academic Achievement and Problem Behavior of Urban Secondary School Students in Bangladesh. International J Social Sci. 8(1):001-10.

7) Fergusson DM, John Horwood L, Ridder EM. Show me the child at seven: the consequences of conduct problems in childhood for psychosocial functioning in adulthood. J Child Psychol Psychiatry. 2005;46(8):837-49.

8) Offord DR, Boyle MH, Fleming JE, Blum HM. Summary of selected results. Can J Psychiatry. 1989;34(6):483-91.

9) Davies S, Heyman I, Goodman R. A population survey of mental health problems in children with epilepsy. Dev Med Child Neurol. 2003;45(5):292-5.

10) Flouri E, Tzavidis N. Psychopathology and prosocial behavior in adolescents from socio-economically disadvantaged families: the role of proximal and distal adverse life events. European Child Adolesc Psychiatry. 2008;17(8):498-506.

11) Elhamid AA, Howe A, Reading R. Prevalence of emotional and behavioural problems among 6-12 year old children in Egypt. Soc Psychiatry Psychiatr Epidemiol. 2009;44(1):8-14.

12) World Health Organization. Iraq Mental Health Survey 2006/7 Report. WHO, Geneva. 2009.

13) Fahmy, S. L., and Sherbiny, A. F. 1988. Determining sample parameters for social classification for health research. Bullet Institute Public Health 13:95-107. 14) Goodman $R$. The extended version of the Strengths and Difficulties Questionnaire as a guide to child psychiatric caseness and 
consequent burden. J Child Psychol psychiatry. 1999;40(5):791-9.

15) Almaqrami MH, Shuwail AY. Validity of the self-report version of the strengths and difficulties questionnaire in Yemen. Saudi Med J. 2004;25(5):592-601.

16) Mahfoud Z, Abdulrahim S, Taha MB, Harpham T, El Hajj T, Makhoul J, Nakkash R, Kanj M, Afifi R. Validation of the Arab Youth Mental Health scale as a screening tool for depression/anxiety in Lebanese children. Child Adolesc Psychiatry Ment Health. 2011;5(9) doi: 10.1186/1753-2000-5-9..

17) Cury CR, Golfeto JH. Strengths and difficulties questionnaire (SDQ): a study of school children in Ribeirão Preto. Rev Bras Psiquiatr. 2003;25(3):139-45.

18) Reddy KR , Biswas A, Rao H. Assessment Of Mental Health Of Indian Adolescents Studying In Urban Schools. Malaysian J Paediatr Child Health. 2012;17(2)1-6.

19) Thabet AA, Stretch D, Vostanis P. Child mental health problems in Arab children: application of the strengths and difficulties questionnaire. Int $J$ Soc Psychiatry. 2000;46(4):266-80.

20) Ford T, Goodman R, Meltzer H. The British Child and Adolescent Mental Health Survey 1999: The Prevalence of DSM-IV Disorders. J Am Acad Child Adolesc Psychiatry. 2003;42(10):1203-11.

21) Dodangi N, Ashtiani NH, Valadbeigi

B. Prevalence of DSM-IV TR Psychiatric Disorders in Children and Adolescents of Paveh, a Western City of Iran. Iranian Red Crescent Med J. 2014;16(7):e16743.

22) Syed EU, Hussein SA. Prevalence of emotional and behavioural problems among primary school children in Karachi, Pakistan -multi informant survey. Indian J Pediatr. 2009;76(6):623-7.

23) Slobodskaya HR. The associations among the Big Five, Behavioural Inhibition and Behavioural Approach systems and child and adolescent adjustment in Russia. Personality Individual Differences. 2007;43(4):913-24.

24) Arman S, Keypour M, Maracy M, Attari A. Epidemiological study of youth mental health using Strengths and Difficulties Questionnaire (SDQ). Iranian Red Crescent Med J. 2012;14(6):371.

25) Mohammadi MR, Alavi A, Mahmoodi J, Shahrivar Z, Tehranidoost M, Saadat S. Prevalence of psychiatric disorders amongst adolescents in Tehran. Iranian $J$ Psychiatry. 2008;3(3):100-4.

26) Yao $S$, Zhang $C$, Zhu $X$, Jing $X$, McWhinnie CM, Abela JR. Measuring adolescent psychopathology: Psychometric properties of the self-report Strengths and Difficulties Questionnaire in a sample of Chinese adolescents. J Adolesc Health. 2009;45(1):55-62.

27) Wille D-PN, Bettge S, Wittchen H-U, Ravens-Sieberer U. How impaired are children and adolescents by mental health problems? Results of the BELLA study. Eur Child Adolesc Psychiatry. 2008;17(1):42-51.

28) Rabbani A, Mahmoudi-Gharaei J, Mohammadi MR, Motlagh ME, Mohammad K, Ardalan G, et al. Mental health problems of Iranian female adolescents and its association with pubertal development: a nationwide study. Acta Med Iran. 2012;50(3):169-76.

29) Giannakopoulos G, Tzavara C, Dimitrakaki C, Kolaitis G, Rotsika V, Tountas Y. The factor structure of the Strengths and Difficulties Questionnaire (SDQ) in Greek adolescents. Ann Gen Psychiatry. 2009;8(20) doi: 10.1186/1744859X-8-20.

30) Pastor PN, Reuben CA, Duran CR. Identifying Emotional and Behavioral Problems in Children Aged 4-17 Years: United States, 2001-2007. National Health Statistics Reports. National Center for Health Statistics. 2012;(48)1-18. 
31) Pathak R, Sharma RC, Parvan U, Gupta B, Ojha RK, Goel N. Behavioural and emotional problems in school going adolescents. Australas Medical J.

2011;4(1):15-21.

32) Ez-Elarab HS, Sabbour SM, Gadallah

MA, Asaad TA. Prevalence and risk factors of violence among elementary school children in Cairo. J Egypt Public Health Assoc. 2007;82:127-46.

33) Hecker T, Hermenau K, Isele D, Elbert T. Corporal punishment and children's externalizing problems: A crosssectional study of Tanzanian primary school aged children. Child abuse neglect. 2014: 38(5):884-92.

34) Ma J, Han Y, Grogan-Kaylor A, Delva J, Castillo M. Corporal punishment and youth externalizing behavior in Santiago, Chile. Child abuse neglect. 2012;36(6):48190.
35) Pinheiro PS. World report on violence against children. 2006. Available at https://calio.dspacedirect.org/handle/11212/1 031. Assessed on August, 15, 2014.

36) Strazdins L, OBrien LV, Lucas N, Rodgers B. Combining work and family: Rewards or risks for children's mental health? Soc Sci Med. 2013;87:99-107. 37) Kessler R, Gruber M, Sampson N. Validation Studies of Mental Health Indices in the National Health Interview Survey. Report presented to the Centers for Disease Control December 21, 2006; Harvard Medical School, Boston, MA. 2005. Available at: http://www.hcp.med.harvard.edu/ncs/scales. php. Assessed on August, 15, 2014 
Table (1a) Sociodemographic characteristics of the studied group

\begin{tabular}{|c|c|c|c|}
\hline \multicolumn{2}{|l|}{ Characteristics } & \multirow{2}{*}{\begin{tabular}{|l|} 
Number \\
$\mathrm{n}=476$
\end{tabular}} & \multirow{2}{*}{\begin{tabular}{|l|}
$\%$ \\
17.4 \\
\end{tabular}} \\
\hline Age & 13 & & \\
\hline & 14 & 86 & 18.1 \\
\hline & 15 & 87 & 18.3 \\
\hline & 16 & 86 & 18.1 \\
\hline & 17 & 134 & 28.2 \\
\hline \multirow[t]{2}{*}{ Sex } & Male & 260 & 54.6 \\
\hline & Female & 216 & 45.4 \\
\hline \multirow[t]{2}{*}{ Marital status (family) } & Married & 425 & 89.3 \\
\hline & Separated & 51 & 10.7 \\
\hline \multirow[t]{4}{*}{ Maternal education } & Illiterate/ & 111 & 23.3 \\
\hline & Basic & 213 & 44.7 \\
\hline & Secondary/ & 100 & 21.0 \\
\hline & \begin{tabular}{|l|} 
University \\
\end{tabular} & 52 & $10.9 \%$ \\
\hline \multirow[t]{2}{*}{ Maternal work } & HW & 431 & 90.5 \\
\hline & Work & 45 & 9.5 \\
\hline \multirow[t]{4}{*}{ Paternal education } & Illiterate/ & 49 & 10.3 \\
\hline & Basic & 113 & 23.7 \\
\hline & Secondary/ & 171 & 35.9 \\
\hline & University & 143 & 30.0 \\
\hline \multirow[t]{3}{*}{ Paternal job } & Professional & 296 & 62.2 \\
\hline & Manual & 116 & 24.4 \\
\hline & Mo or & 64 & 13.4 \\
\hline \multirow[t]{3}{*}{ Social level } & Low & 119 & 25.0 \\
\hline & Middle & 312 & 65.5 \\
\hline & High & 45 & 9.5 \\
\hline
\end{tabular}


Table (1b) Personal characteristics of the studied group

\begin{tabular}{|c|c|c|c|}
\hline \multicolumn{2}{|l|}{ Characteristics } & $\begin{array}{l}\text { Number } \\
\mathrm{n}=476\end{array}$ & $\%$ \\
\hline \multirow[t]{2}{*}{ School type } & Public & 426 & 89.5 \\
\hline & Private & 50 & 10.5 \\
\hline \multirow[t]{2}{*}{ School grade } & Preparatory & 260 & 54.6 \\
\hline & Secondary & 216 & 45.4 \\
\hline \multirow[t]{3}{*}{ Child order } & The first & 178 & 37.4 \\
\hline & The middle & 210 & 44.1 \\
\hline & The last & 88 & 18.5 \\
\hline \multirow[t]{3}{*}{ Sibling number } & $1---2$ & 83 & 17.4 \\
\hline & $3---4$ & 256 & 53.8 \\
\hline & $>4$ & 137 & 28.8 \\
\hline $\begin{array}{l}\text { Domestic Violence } \\
\text { exposure }\end{array}$ & & 108 & 22.7 \\
\hline \multirow[t]{2}{*}{ Special habits } & Smoking & 11 & 2.3 \\
\hline & Drugs & 27 & 5.7 \\
\hline \multirow[t]{2}{*}{ School } & Frequent absence & 138 & 29.0 \\
\hline & Poor achievements & 49 & 10.3 \\
\hline \multirow[t]{3}{*}{ School Punishment } & Never or rare & 178 & 37.4 \\
\hline & Sometimes & 274 & 57.6 \\
\hline & Always & 24 & 5.0 \\
\hline
\end{tabular}


Table (2a) Strength and difficulty questionnaire scores among the studied group

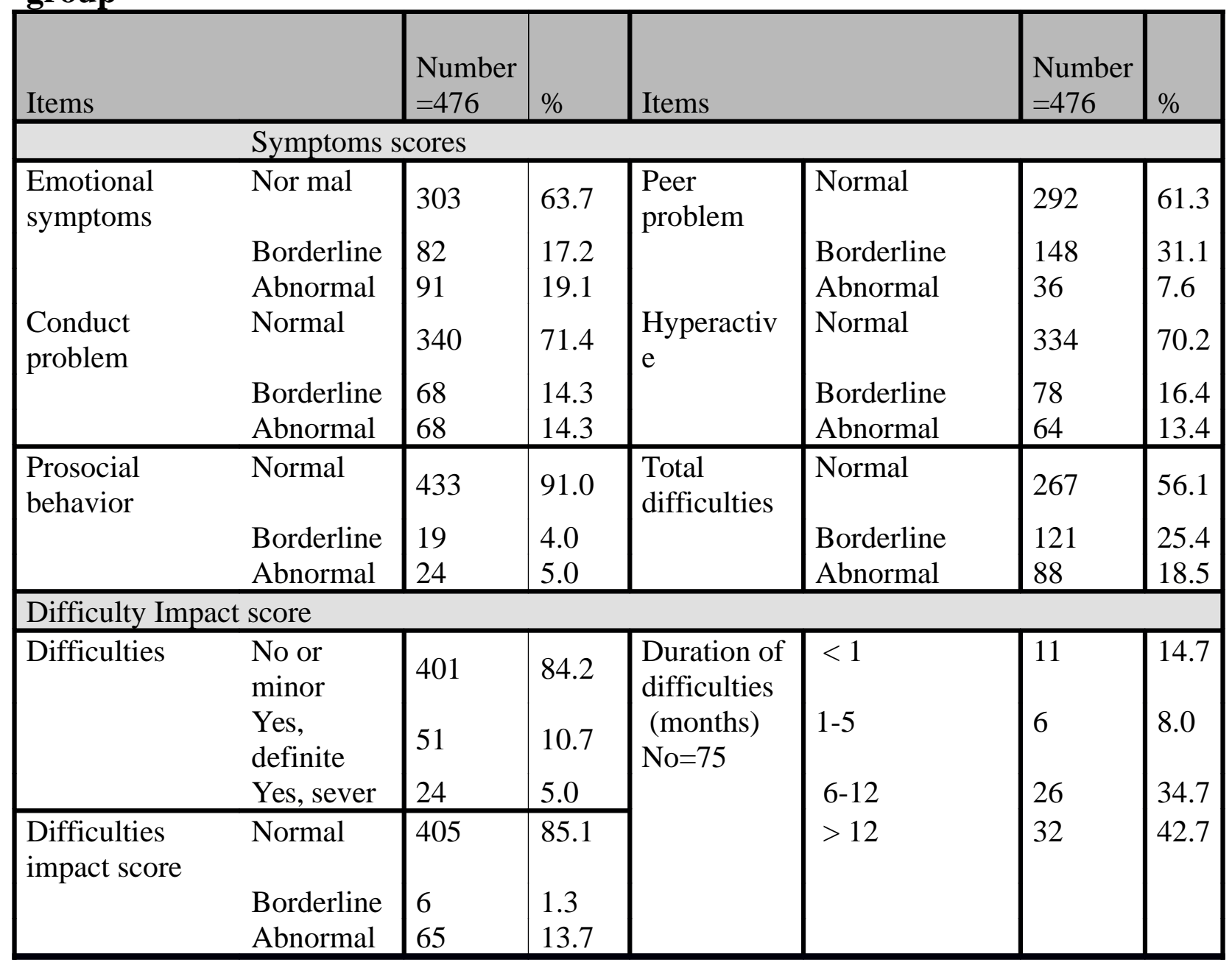


Table (2b) Strength and difficulty questionnaire scores among the studied group

\begin{tabular}{|l|c|c|c|c|c|c|}
\hline & \multicolumn{2}{|c|}{ Never / A little } & \multicolumn{2}{c|}{ Quit a lot } & \multicolumn{2}{c|}{ A Great Deal } \\
\hline Difficulties interfere with & No. & \% & No. & \% & No. & \% \\
\hline Daily life at home & 432 & 90.8 & 24 & 5.0 & 24 & 5.0 \\
\hline Friendships & 436 & 91.6 & 14 & 2.9 & 26 & 5.5 \\
\hline Difficulties upset or distress & 424 & 89.1 & 26 & 5.5 & 26 & 5.5 \\
you & & & & & & \\
\hline School learning & 426 & 89.5 & 17 & 3.6 & 33 & 6.9 \\
\hline leisure activity & 446 & 93.7 & 17 & 3.6 & 13 & 2.7 \\
\hline $\begin{array}{l}\text { Difficulties make it harder } \\
\text { for people around you }\end{array}$ & 436 & 91.6 & 19 & 4.0 & 21 & 4.4 \\
\hline
\end{tabular}

Table (3) Association between total difficulty score and impact score with sociodemographic characteristics of the studied group

\begin{tabular}{|c|c|c|c|c|c|c|}
\hline \multirow[b]{3}{*}{ Characteristics } & \multicolumn{3}{|c|}{ Total difficulty score } & \multicolumn{3}{|c|}{ Difficulty impact score } \\
\hline & \multicolumn{2}{|c|}{ Abnormal } & \multirow[t]{2}{*}{ P-value } & \multicolumn{2}{|c|}{ Abnormal } & \multirow{2}{*}{$\begin{array}{l}\mathrm{P}- \\
\text { value }\end{array}$} \\
\hline & $\begin{array}{l}\text { Numbe } \\
\mathrm{r}\end{array}$ & $\begin{array}{l}\text { Row } \\
\%\end{array}$ & & Number & Row\% & \\
\hline School type & 72 & 16.9 & .009 & 58 & 13.6 & .940 \\
\hline
\end{tabular}




\begin{tabular}{|c|c|c|c|c|c|c|c|}
\hline & Private & 16 & 32.0 & & 7 & 14.0 & \\
\hline School grade & $\begin{array}{l}\text { Preparatory } \\
\text { Secondary }\end{array}$ & $\begin{array}{l}40 \\
48\end{array}$ & $\begin{array}{l}15.4 \\
22.2\end{array}$ & .056 & $\begin{array}{l}24 \\
41\end{array}$ & $\begin{array}{l}9.2 \\
19.0\end{array}$ & .002 \\
\hline Age & $\begin{array}{l}13 \\
14 \\
15 \\
16 \\
17\end{array}$ & $\begin{array}{l}11 \\
13 \\
17 \\
16 \\
31\end{array}$ & $\begin{array}{l}13.3 \\
15.1 \\
19.5 \\
18.6 \\
23.1\end{array}$ & .387 & $\begin{array}{l}2 \\
12 \\
10 \\
13 \\
28\end{array}$ & $\begin{array}{l}2.4 \\
14.0 \\
11.5 \\
15.1 \\
20.9\end{array}$ & .004 \\
\hline Sex & $\begin{array}{l}\text { Male } \\
\text { Female }\end{array}$ & $\begin{array}{l}46 \\
42\end{array}$ & $\begin{array}{l}17.7 \\
19.4\end{array}$ & .624 & $\begin{array}{l}31 \\
34\end{array}$ & $\begin{array}{l}13.1 \\
14.4\end{array}$ & .687 \\
\hline $\begin{array}{l}\text { Sibling } \\
\text { number }\end{array}$ & $\begin{array}{l}1---2 \\
3---4 \\
>4\end{array}$ & $\begin{array}{l}11 \\
49 \\
28\end{array}$ & $\begin{array}{l}13.3 \\
19.1 \\
20.4\end{array}$ & .381 & $\begin{array}{l}10 \\
32 \\
23\end{array}$ & $\begin{array}{l}12.0 \\
12.5 \\
16.8\end{array}$ & .447 \\
\hline Child rank & $\begin{array}{l}\text { The first } \\
\text { The middle } \\
\text { The last }\end{array}$ & $\begin{array}{l}30 \\
42 \\
16\end{array}$ & $\begin{array}{l}16.9 \\
20.0 \\
18.2\end{array}$ & .726 & $\begin{array}{l}21 \\
35 \\
9\end{array}$ & $\begin{array}{l}11.8 \\
16.7 \\
10.2\end{array}$ & .222 \\
\hline $\begin{array}{l}\text { Marital status } \\
\text { (family) }\end{array}$ & $\begin{array}{l}\text { Married } \\
\text { Separated/divorced/widow }\end{array}$ & $\begin{array}{l}72 \\
16 \\
\end{array}$ & $\begin{array}{l}16.9 \\
31.4\end{array}$ & .012 & $\begin{array}{l}57 \\
8 \\
\end{array}$ & $\begin{array}{l}13.4 \\
15.7 \\
\end{array}$ & .655 \\
\hline $\begin{array}{l}\text { Paternal } \\
\text { education }\end{array}$ & $\begin{array}{l}\text { illiterate or Reads\& writes } \\
\text { Basic } \\
\text { Secondary / vocational } \\
\text { University or higher }\end{array}$ & $\begin{array}{l}9 \\
18 \\
29 \\
32\end{array}$ & $\begin{array}{l}18.4 \\
15.9 \\
17.0 \\
22.4\end{array}$ & .533 & $\begin{array}{l}4 \\
9 \\
26 \\
26\end{array}$ & $\begin{array}{l}8.2 \\
8.0 \\
15.2 \\
18.2\end{array}$ & .066 \\
\hline Paternal job & $\begin{array}{l}\text { professional or } \\
\text { semiprofessional } \\
\text { Manual } \\
\text { no or periodic work }\end{array}$ & $\begin{array}{l}52 \\
18 \\
18\end{array}$ & $\begin{array}{l}17.6 \\
15.5 \\
28.1 \\
\end{array}$ & .091 & $\begin{array}{l}37 \\
17 \\
11\end{array}$ & $\begin{array}{l}12.5 \\
14.7 \\
17.2 \\
\end{array}$ & .574 \\
\hline $\begin{array}{l}\text { Maternal } \\
\text { education }\end{array}$ & $\begin{array}{l}\text { illiterate or Reads and writes } \\
\text { Basic } \\
\text { Secondary / vocational } \\
\text { University or higher }\end{array}$ & $\begin{array}{l}20 \\
38 \\
17 \\
13\end{array}$ & $\begin{array}{l}18.0 \\
17.8 \\
17.0 \\
25.0\end{array}$ & .640 & $\begin{array}{l}21 \\
27 \\
8 \\
9\end{array}$ & $\begin{array}{l}18.9 \\
12.7 \\
8.0 \\
17.3 \\
\end{array}$ & .108 \\
\hline Maternal work & $\begin{array}{l}\text { Housewife } \\
\text { work }\end{array}$ & $\begin{array}{l}80 \\
8\end{array}$ & $\begin{array}{l}18.6 \\
17.8\end{array}$ & .897 & $\begin{array}{l}54 \\
11\end{array}$ & $\begin{array}{l}12.5 \\
24.4\end{array}$ & .027 \\
\hline Social level & $\begin{array}{l}\text { Low } \\
\text { Middle } \\
\text { High }\end{array}$ & $\begin{array}{l}20 \\
57 \\
11\end{array}$ & $\begin{array}{l}16.8 \\
18.3 \\
24.4\end{array}$ & .524 & $\begin{array}{l}13 \\
41 \\
11\end{array}$ & $\begin{array}{l}10.9 \\
13.1 \\
24.4\end{array}$ & .072 \\
\hline
\end{tabular}

All $p$ values by Chi square test

Table (4) Association between total difficulty score and impact score with personal, and school characteristics of the studied group

\begin{tabular}{|c|c|c|c|c|c|c|c|}
\hline \multirow[b]{3}{*}{ Characteristics } & & \multicolumn{3}{|c|}{ Total difficulty score } & \multicolumn{3}{|c|}{ Difficulty impact score } \\
\hline & & \multicolumn{2}{|c|}{ Abnormal } & \multirow[t]{2}{*}{$\mathrm{P}$ value } & \multicolumn{2}{|c|}{ Abnormal } & \multirow[t]{2}{*}{$P$ value } \\
\hline & & $\begin{array}{l}\text { Numbe } \\
\mathrm{r}\end{array}$ & Row \% & & $\begin{array}{l}\text { Numbe } \\
\mathrm{r}\end{array}$ & Row \% & \\
\hline Smoking & $\begin{array}{l}\text { Yes } \\
\text { No }\end{array}$ & $\begin{array}{l}3 \\
85\end{array}$ & $\begin{array}{l}27.3 \\
18.3\end{array}$ & $.435^{*}$ & $\begin{array}{l}4 \\
61\end{array}$ & $\begin{array}{l}36.4 \\
13.1\end{array}$ & $.050 *$ \\
\hline
\end{tabular}




\begin{tabular}{|c|c|c|c|c|c|c|c|}
\hline Substance Abuse & $\begin{array}{l}\text { Yes } \\
\text { No }\end{array}$ & $\begin{array}{l}8 \\
80\end{array}$ & $\begin{array}{l}29.6 \\
17.8\end{array}$ & $.129 *$ & $\begin{array}{l}5 \\
6\end{array}$ & $\begin{array}{l}18.5 \\
13.4\end{array}$ & $.396^{*}$ \\
\hline Domestic violence exposure & $\begin{array}{l}\text { Yes } \\
\text { No }\end{array}$ & $\begin{array}{l}27 \\
61\end{array}$ & $\begin{array}{l}25.0 \\
16.6\end{array}$ & . 047 & $\begin{array}{l}22 \\
43\end{array}$ & $\begin{array}{l}20.4 \\
11.7\end{array}$ & .021 \\
\hline School punishment & $\begin{array}{l}\text { Never/ } \\
\text { rare } \\
\text { Sometimes } \\
\text { Always }\end{array}$ & $\begin{array}{l}29 \\
49 \\
10\end{array}$ & $\begin{array}{l}16.3 \\
17.9 \\
41.7\end{array}$ & .010 & $\begin{array}{l}28 \\
27 \\
10\end{array}$ & $\begin{array}{l}15.7 \\
9.9 \\
41.7\end{array}$ & $<.001$ \\
\hline $\begin{array}{l}\text { Frequent absence from } \\
\text { school }\end{array}$ & $\begin{array}{l}\text { Yes } \\
\text { No }\end{array}$ & $\begin{array}{l}35 \\
53\end{array}$ & $\begin{array}{l}25.4 \\
15.7\end{array}$ & .014 & $\begin{array}{l}30 \\
35\end{array}$ & $\begin{array}{l}21.7 \\
10.4\end{array}$ & .001 \\
\hline Scholastic achievement & $\begin{array}{l}\text { Good } \\
\text { Poor }\end{array}$ & $\begin{array}{l}82 \\
6\end{array}$ & $\begin{array}{l}19.2 \\
12.2\end{array}$ & .235 & $\begin{array}{l}57 \\
8\end{array}$ & $\begin{array}{l}13.3 \\
16.3\end{array}$ & .565 \\
\hline
\end{tabular}

* P value of Fishers exact test otherwise of Chi square test

Table (5) Significant predictors for abnormal total difficulty score and impact score among the studied group

\begin{tabular}{|c|c|c|}
\hline & $\begin{array}{l}\text { Odds ratio ( } 95 \% \\
\text { confidence interval) }\end{array}$ & $P$ value. \\
\hline \multicolumn{3}{|l|}{ otal difficulties score } \\
\hline Private / public school & $3.037(1.397-6.600)$ & .005 \\
\hline Secondary / preparatory students & $1.851(1.039-3.299)$ & .037 \\
\hline Single /married parent & $2.106(1.068-4.152)$ & .032 \\
\hline Frequent punishment at school & $2.725(1.087-6.828)$ & .032 \\
\hline Constant & .092 & $<0.001$ \\
\hline \multicolumn{3}{|l|}{ Difficulties impact score } \\
\hline Secondary / preparatory students & $2.710(1.490-4.928)$ & .001 \\
\hline Working mother / house wife & $2.466(1.108-5.490)$ & .027 \\
\hline Frequent punishment at school & $4.808(1.842-12.547)$ & .001 \\
\hline Smoker / nonsmoker & $3.979(1.027-15.419)$ & .046 \\
\hline SDQ total score abnormal / normal \& borderline & $4.277(2.373-7.709)$ & $<0.001$ \\
\hline Constant & .046 & $<0.001$ \\
\hline
\end{tabular}

